\title{
THE PROSPECTS OF SHARIA HOTEL BUSINESS IN INDONESIA (CASE STUDY IN SURABAYA CITY)
}

\author{
Dr. Sri EndahNurhidayati, S.Sos, M.Si a, Andy UmardionoS.Sos, M.Si. b, Novianto Edi S.S.T.Par, M.Si c \\ abc Faculty of Vocational Airlangga University, Surabaya, Indonesia \\ Corresponding email: sriendah.nurhidayati@fisip.unair.ac.id
}

Abstract

Islamic tourism is an activity that provides the tourism facilities and services with the concepts and values of Islam. Islamic tourism terminology in Indonesia is known as Sharia Tourism, and is internationally known as Islamic tourism. One important part that must exist in Islamic tourism development is the availability of Sharia accommodation or Sharia hotel. Sharia Hotel is the hotel operations and services adapted to Islamic principles or guidelines of Islam.

This article describes the characteristics of sharia hotels, and analyzes the business prospects of sharia hotel. The research location in Surabaya, which is one of the business centers in Indonesia.The study used a qualitative approach. Data collected through interviews and observations.

The results showed that characteristics of sharia hotels include: (1) physical aspect: the interior and exterior of the hotel using the attributes of Islamic (calligraphy, building pillared resembles a mosque, buildings without human figures or animals and ornaments upon which are symbols of Islam; (2) human resource: for female staff wear the veil (hijab), protective clothing and loose, use makeup simple, and do not use excessive jewelry and for the male staff wearing a courteous, long sleeves and muslim caps ; (3) service: greeting using the greeting Islamic, attitude of staff polite, gentle and smile sympathetically; (4) facilities: halal restaurants, filter pornography on the TV channel, there is no facility music room, night club, bar with alcohol, prostitution, gambling, and facilities which is forbidden in Islam, the pool is enclosed (indoor) and separate male and female, played Islamic music; (5) Policy: allow only guests and the mukhrim to stay in one room, payment of Islamic bank (sharia bank); (6) Managerial: timely payment of employee salaries, in cooperation with Islamic banks.

The market of sharia hotel is conducting pilgrimage travelers, families and Muslim businessmen. The market reasons for using sharia hotel in general is closed access to place of pilgrimage destination and other Islamic destinations (mosque). While the market in the form of sharia family choose the hotel because it is quieter, safer for families and guaranteed halal food served.

Keywords: Sharia Hotel, Sharia Accommodation, Sharia Tourism, Islamic Tourism.

\section{Introduction}

Islamic tourism has become the trend in many countries such as Malaysia, Brunei, Turkey, Dubai, Maldives, even Australia, Thailand, Singapore, Korea, Japan, Taiwan and China have already developed a islamic tourism. Many countries are aggressively working on Sharia / Islamic / Islamic tours because the Muslim tourist market is very promising. DinarStandard, a US-based company interested in Muslim lifestyle markets, reported the survey results in its latest annual report, the Dinar Standard reveals, Muslim tourist spending was recorded at US \$ 126 billion in 2011 and is 
expected to be US $\$ 192$ billion by 2020. Muslim The world currently reaches 1.8 billion people, or $28 \%$ of the total world population, spread across 148 countries.

The potential of Syariah / Islamic tourism is also felt in the ASEAN region. Malaysia, a cognate neighbor, has received the arrival of 5.7 million Muslim tourists from the total of 24 million foreign tourists who come to the country. Syariah / Islamic / Islamic Tourism contributes enormously to the country's foreign exchange earnings so that in 2009, the Malaysian government established the Islamic Tourism Center, at the level of the Directorate General under the Ministry of Tourism of Malaysia. The growth of Syariah / Islamic tourism market can also be seen in the World Islamic Tourism Mart held in Kuala Lumpur, Malaysia, last year. The event was followed by tour and travel companies from 50 countries. They come to offer tour packages for Muslim tourists.

Thomson Reuters State-of-the-Islamic Economy report defines and provides a view of the Islamic economy as well as its potential to facilitate investments and industry growth (Comdec, 2016). The development of tourism generates specific market requirements such as kosher hotels, transport halal (kosher airlines), food kosher restaurants, kosher and halal tour packages finance. Therefore, halal tourism consists of different sectors which are related with each other (Akyol \& Kilinc, 2014).

Indonesia's sharia-based tourism industry is still far behind compared to neighboring countries such as Thailand, Singapore, Korea, Japan, Taiwan and China. Travel and banking is already a trend in some countries, namely Malaysia and even Thailand, Singapore, Korea, Japan, Taiwan and China. Indonesia through the Ministry of Tourism and Creative Economy has officially established itself as a Sharia / Islamic / Islamic World Travel Destination. On December 20, 2012 Sharia / Islamic / Islamic Tourism can be defined as a variety of tourism activities supported by various facilities and services provided by the community, businessmen, government and local governments that comply with Sharia / Islamic / Islamic provisions.

The potential of Shariah tourism in the future is expected to increase, because Muslim tourists are the main market share of sharia tourism. The availability of halal food and beverages and providing praying facilities, including a clean, safe, comfortable and comfortable place, is a must for an Islamic sharia hotel business, but can be utilized by all walks of life, even able to improve product standards and better service compared to tourism services in general. Data Ministry of Tourism and Creative Economy (Kemenparekraf), the world's Muslim population currently reaches 1.8 billion or $28 \%$ of the total world population is a large enough market potential. Currently Muslim tourists have contributed about US \$ 126 billion in 2011. Globally, the Muslim population of the world reached 1.6 billion, or 23 percent of the total world population (Vivanews, 2012). The contribution of Muslim tourists reaches USD 126 billion. The Central Bureau of Statistics recorded the number of foreign tourists who entered Indonesia until October 2012 reached 1,270,437 people. Currently in Indonesia there are 9 tourist destinations that currently have the potential to be promoted as a destination for Sharia Tourism, namely West Sumatra, Riau, Lampung, Banten, Jakarta, West Java, East Java, Makasar, Lombok. As the first step of Indonesia through the Ministry of Tourism introduces the package of Islamic tourism tour or package tour Muslim nusantara end of 2012. One of the important means that must exist in the development of Islamic tourism is the availability of sharia hotels or sharia accommodation. Sharia hotels are hotels whose operations and services have adapted to the principles of sharia or guidelines of Islamic teachings.

The development of shariah tourism in Surabaya encourages the growth of shariah-based tourism service system that is based on Islamic teachings. The most developed sharia tourism product is a 
pilgrimage to the graves of the Wali (people who spread Islam), visiting old or historic mosques (Cheng Ho Mosque, Ampel Mosque, Kemayoran Mosque, Al Falah Mosque, Rahmat Mosque, etc.) The iconic modern mosque (Al Akbar Mosque). Pilgrimage tourism products then give birth to the needs of sharia accommodation which is a supporting needs of tourists. The sharia hotel business then expanded along with the market increase. If initially the hotel market sharia is a pilgrim and then developed into a general consumer market that is the businessmen and consumers who travel with family. According to Osman (2015), staying at the hotel at the same sharia is part of the learning process of the family .. "based on Islamic teaching that encourages individuals, especially women and children to travel with Reviews their muhrim roomates means that someone who has blood relations with them to provide them with Security ... "

This article would like to describe the characteristics of sharia hotels and business prospects of sharia hotels in Surabaya.

\section{Literature Review}

The concept of sharia tourism is not specifically found in the global literature. The term is widely used in literature menkaitkan Isalam tourism and are "Islamic Tourism" or halal tourism. Likewise isitilah shariah hotel refers to the halal understanding of hotels or kosher accommodation. In a narrow sense, Islamic tourism is defined as religious tourism ie Visiting places of worship throughout the Islamic World) and in the broad sense is defined as the type of tourism that implements Islamic values. The concept of sharia tourism is developed from the terminology of religion tourism or religious tourism ie tourism activities that are closely related to religion as a strong motive for traveling, religious buildings, rituals, festivals and religious events as an important tourist attraction believed by adherents (Henderson, 2003).

The term sharia hotels in global terms is called kosher hotel or halal acokomadi. Isitilah shariah is a component of Islamic teachings that regulate the life of a Muslim both in the field of worship (habluminallah) and in the field of muamallah (hablumminannas) which is the actualization of the creed that became his belief. "(Amir Machmud, 2010, p 24) and hotels with the concept of ordinary sharia services Called Hotel Sharia.

Features of demand and supply of hospitality services within an Islamic realm. Actually, there are no formal criteria for the Sharia or Halal hotel Compliant Hotel. However, some of the Muslim writers describe some basic characteristics of Shariah Compliance Hotels as mentioned in the following (Samori \& Saturday, 2014) :( a) Halal foods and no alchohol to be served in the premises or hotels, (b) Having the Holy Book Quran, prayer mat and arrow that indicating the direction of qiblat, (d) Prayer room is available in the premises and hotels, (e) No inappropriate entertainment, (f) Predominantly Muslim (G) Separate salon, recreational facilities and swimming pool for men and women, (h) Separate room / floor for unmarried couple between male and female, (i) Tourists dressing code, (j) No gambling and alchohol drinks in the hotel lobby or restaurant, (k) No prohibited foods and beverages in the hotel fridge. Saudi Arabia for example is considered the leading center to provide Shariah- Compliant hotels because of its role to cater for over 8 million pilgrims each year. (Henderson, 2010).Meanwhile, the more stringent scope of Halal hotel industry could be adopted where Islamic resorts and hotels as well as Islamic destinations and programs are shaping some roomates tourist activities can be said to be complying with Islamic teaching. Islamic resorts funded and owned by Islamic finance institutions have also free accommodation, no indo in-door disco / nightlife hotel; Provide gender segregated fitness and sports facilities to avoid free pooling and recreational facilities (Henderson, 2003; Al-Hamarneh \& 
Steiner, 2004) and availability of prayer-rooms on site, women's floor and Islamic entertainment programs .

Islamic tourism is a new tourist destination in the world today. There are 54 Muslim countries in the world's potential markets. Most of the countries are located in the important point of the world. Wall and Mathieson recognize that: "Religion has become a great power to move people to travel to religious centers in many parts of the world (Wall \& Mathieson, 2006, p. 251). In some predominantly Muslim countries tourism planning and development of Islam is quite neat and professional, for example: Malaysia, Turkey, Qatar, etc. (Specifically Santos (2003: 40) describes 5 characteristics of religious tourism (1) are voluntary, (2) motivated religion, (3) equipped with other motivations, (4) the purpose is religious sites, and (5) travel to destinations is not a religious practice.

Bhuiyan, et al., (2011, p. 1135) notes there are 2 important aspects that must be fulfilled related to Islamic tourism are aspects (1) satisfaction in Islamic tourism and (2) tourism object. Islamic tourism is one of the most important resources especially in Muslim countries that have rich and varied inheritance. This permanent wealth and property has attracted Muslim visitors throughout history and will also attract tourists (including non-Muslims) to come to visit.

Shackley (2003, p. 161) establishes some extent of religious tourism attractions (Islam), namely (1) natural phenomena (lakes, mountains, beaches, islands etc.) that are considered to help people remember the greatness of God, (2) (3) religious themed buildings, (4) religious events, (5) special events with religious meaning (religious festivals).

According to the Regulation of the Minister of Tourism and creative economy number 2 of 2014, it can be defined that Sharia Hotel business is a hotel business whose organization must comply with sharia principles as regulated by fatwas and / or approved by the National Sharia Council of Indonesian Council of Ulama (DSN-MUI) . The classification of Sharia hotels is determined through the Hotel Sharia business certification based on the result of the assessment of the basic requirements as well as the fulfillment of absolute criteria applicable to the syriah hotel business, covering product aspect, service aspect and management aspect.

Sharia hotels are now starting to emerge in various regions according to data from the current Global Muslim travel index of sharia hotels in Indonesia that have certified 37 hotels and as many as 150 hotels to operational sharia. There are several sharia hotels located on the island of Java as an example: hotel sofyan in Jakarta is a pioneer of sharia hotels in Indonesia and other shariah hotels then in the area of Solo there is a four-star sharia hotel built by Tommy Soeharto, in the area of Surabaya there are several sharia hotels around the grave of Sunan Ampel like Grand Kalimas Hotel, Quyd Royal Hotel and Kyriad Pesonna Hotel. The presence of this sharia hotel because of demand from consumers who start wanting services based on sharia in accordance with Islamic religion, because in Indonesia a majority of the population is Islam, so to meet these needs many hotels are beginning to apply the concept of sharia in its service.

Santoso (2007) affirmed the religious journey as important in the development of tourism. Although religion is more aimed at the things that are meaningful and spiritual that is in the realm of individual consciousness, religion can then become a collective consciousness, which then leads to the motivation to learn and study a religion in the meaning and also empirically as well as proof about the greatness of a religion. The motivation to learn through this proof has brought awareness of the visit to the historic places of Islam, pilgrimage to the tombs of Islamic leaders who may be in a distant region, which may be in a State outside the country. This has 
directly led to demand for tourism due to the availability of "availability" of Islamic historical places as a means of learning Islam itself.

In other facts, some Muslim-majority countries have proven to have many famous sights, and that can be seen in several countries in the Middle East, as well as North Africa. Other facts can also be found that in some predominantly Muslim countries having good planning with the development of tourism in their country, the presence of tourism industry management is quite neat and professional, for example; Malaysia, Turkey, Qatar, and so forth (Dallen, 2007).

\section{Methodology}

This study uses a qualitative descriptive approach that aims to describe the phenomenon in depth. This type of research is appropriate for tourism studies because it has a specific, deep and holistic range.

The research location determined purposively in Surabaya. The reason for choosing the location of research because the city of Surabaya has the potential of Islamic tourism with various buildings of worship (mosque) such as Al Akbar, Ampel, Cheng Ho and so forth that hold its own charm. Surabaya also has historical value for having been passed by Walisongo in conducting syiar of Islam. Surabaya is also the capital of East Java province so that became the center of East Java tourism development. Surabaya also has considerable tourism potentials (shopping, heritage, artificial parks, nature tourism / ecotourism, MICE and special interest tours) making it possible to be associated with the potential of sharia as a holistic tourist attraction.

Primary data collection was conducted through interviews using questionnaires, in-depth interviews and observation. The target of the research is sharia hotel business owners, and consumers who stay at sharia hotels. Interviews were conducted with in depth interviews. To complete the primary data, secondary data collection will be conducted using data from BPS, and related SKPD, and other secondary data required. Secondary and secondary data obtained will be analyzed to answer the research problem. Data analysis was performed with content and interactive analysis. Content analysis is intended to conduct analysis through important and significant interview citations to answer the research problem

\section{Result and discussion}

Surabaya is one of the regional cities that became the center of the spread of Islam in the province of East Java. In Surabaya we find many historical places that describe the process of spreading Islam and marked by the construction of places of worship (mosque) which until now can still be visited. Cheng Ho Mosque, Sunan Ampel religious area, Kemayoran Mosque, Al Falah Mosque, Al Akbar Mosque Complex, Al Fitrah Pesantren, Mbak Bungkul Tombs are some of the most important religious tourism objects in Surabaya that are visited by Muslim pilgrims.

In the vicinity of religious tourism objects then emerged the need for pilgrims to stay because the peziaran want to spend the night time to worship in holy places. Then popping accommodation around the object. Currently there are about 73 hotels around the Ampel Mosque, 4 of which are sharia hotels. Generally a non-star hotel owned and managed by local people. From the Hotel standing around Ampel Mosque and Kemayoran dominates the number. Below is the Syariah hotel data in Surabaya: 
Table 1: Sharia hotels in Surabaya City

\begin{tabular}{|l|l|l|}
\hline $\begin{array}{l}\text { N } \\
\text { O }\end{array}$ & HOTEL NAME & LOCATION \\
\hline 1 & $\begin{array}{l}\text { Sofyan Inn Grand } \\
\text { Kalimas }\end{array}$ & Jl. KH Mas Mansyur 151, Surabaya \\
\hline 2 & Walan Syariah Hotel & Jl. Raya Sedati Agung 1 Betro Juanda \\
\hline 3 & $\begin{array}{l}\text { Nisa Home Shariah } \\
\text { Homestay }\end{array}$ & $\begin{array}{l}\text { Jl. Gubeng Kertajaya VI B No.3, Gubeng, } \\
\text { Surabaya }\end{array}$ \\
\hline 4 & $\begin{array}{l}\text { Graha Cantiq Syariah } \\
\text { Guest House }\end{array}$ & Raya Dukuh Pakis No.23, Surabaya \\
\hline 5 & Andita Syariah Hotel & Jl. Cokroaminoto No.2, Surabaya \\
\hline 6 & Sharia Inn Surabaya & Jl. Prenjak No. 2 \\
\hline 7 & Hotel Walisongo & Jalan Petukangan No.34, Semampir, \\
\hline 8 & Quds Royal Hotel & $\begin{array}{l}\text { Jl. Sultan Iskandar Muda No. 85 Ampel } \\
\text { Semampir Surabaya }\end{array}$ \\
\hline 9 & Andalus Hotel & $\begin{array}{l}\text { Jl.Sultan Iskandar Muda No.65, Ampel, } \\
\text { Semampir, }\end{array}$ \\
\hline 10 & Global In Syariah & Airport Area \\
\hline 11 & Kyriad Pesonna Hotel & Jl. Fortress no. 1 \\
\hline
\end{tabular}

Source: Primary Data 2016

The spread of syariah accommodation is uneven in all areas of Surabaya City. Most are close to the object of sharia tourism such as in the area of North Surabaya which is the center of religious tourism objects in Surabaya. Thus can be said if there is a link between the growth of sharia hotels with the development of pilgrimage tours. Sharia hotels grow around pilgrimage tourism destinations.

When viewed physically there is no significant difference between Sharia hotels and non-Sharia hotels but there are some things that are not found in buildings in sharia hotels such as the use of ornaments or statues of humans or animals whereas in non-sharia hotels are widely used ornaments in the form of human and animal sculpture. In Muslim beliefs the existence of human or animal statues precludes angels from entering the place. The fundamental difference between sharia and non-sharia accommodation can be seen in table 2 .

Table 2: The difference between Sharia hotels and non sharia

\section{The 2. The difference between Sharia hotels and non sharia}

\begin{tabular}{|c|c|c|c|}
\hline No & & Indicator & Non-Sharia \\
\hline 1 & $\begin{array}{l}\text { Physical } \\
\text { enampilan } \\
\text { building }\end{array}$ & $\begin{array}{l}\text { - Interior and exterior } \\
\text { use Islamic attributes } \\
\text { (calligraphy, pillared } \\
\text { building resembling a } \\
\text { mosque) } \\
\text { - Not using human or } \\
\text { animal statues, }\end{array}$ & $\begin{array}{l}\text { - Seldom use Islamic } \\
\text { attributes in interior and } \\
\text { exterior } \\
\text { - Often use decoration in } \\
\text { the form of human or } \\
\text { animal sculpture } \\
\text { - Use more colorful colors. }\end{array}$ \\
\hline
\end{tabular}




\section{Asia Pacific Journal of Advanced Business and Social Studies \\ ISBN (eBook): 9780994365675 | ISSN : 2205-6033 \\ Year: 2017 , Volume: 3, Issue: 2}

\begin{tabular}{|c|c|c|c|}
\hline & & $\begin{array}{l}\text { - Using colors } \\
\text { identical to Islam } \\
\text { (green or white) }\end{array}$ & \\
\hline 2 & Staft & $\begin{array}{l}\text { - For female staff } \\
\text { using veils, closed and } \\
\text { loose clothes, using } \\
\text { simple makeup, and } \\
\text { not using excessive } \\
\text { jewelry } \\
\text { Male staff wearing } \\
\text { polite, long-sleeved and } \\
\text { cape clothes }\end{array}$ & $\begin{array}{l}\text { Both male and female staff } \\
\text { use office style }\end{array}$ \\
\hline 3 & Service & $\begin{array}{l}\text { - Greeting with } \\
\text { greetings Islami } \\
\text { (Assalamualaikum } \\
\text { warohmatullahi } \\
\text { Wabarokatuh) } \\
\text { - Attitude of polite } \\
\text { staff, gentle and } \\
\text { sympathetic smile }\end{array}$ & $\begin{array}{l}\text { Greeting using National or } \\
\text { International greetings. }\end{array}$ \\
\hline 4 & Amenities & $\begin{array}{l}\text { - S arana / equipment } \\
\text { worship Mulsim } \\
\text { (Koran, prayer rug), a } \\
\text { kosher restaurant, filter } \\
\text { pornography on the TV } \\
\text { channel, there is no } \\
\text { facility music room, } \\
\text { night club, bar with } \\
\text { liquor, prostitution, } \\
\text { gambling, and the } \\
\text { facilities were } \\
\text { forbidden in the } \\
\text { religion of Islam . } \\
\text { - The pool is closed } \\
\text { and separated between } \\
\text { men and women, } \\
\text { Play Islamic music; }\end{array}$ & $\begin{array}{l}\text { - Not providing equipment } \\
\text { for Muslim worship, } \\
\text { restaurants universal, no } \\
\text { filter pornography on the } \\
\text { TV channel, there is } \\
\text { amusic room facilities, } \\
\text { night clubs, or bars. } \\
\text { - The pool does not } \\
\text { separatebetween men } \\
\text { and women. } \\
\text { - The music played is } \\
\text { universal }\end{array}$ \\
\hline & Policy & $\begin{array}{l}\text { - Only allowing a } \\
\text { married couple or a } \\
\text { family relationship to } \\
\text { stay in a room } \\
\text { - Payment using }\end{array}$ & $\begin{array}{l}\text { - There is no provision of a } \\
\text { guest staying in a hars } \\
\text { husband or wife room or } \\
\text { there is a family } \\
\text { relationship. }\end{array}$ \\
\hline
\end{tabular}




\begin{tabular}{|l|l|l|l|}
\hline & & Islamic bank (sharia); & $\begin{array}{l}\text { Free payment using any } \\
\text { bank. }\end{array}$ \\
\hline & Managerial: & $\begin{array}{l}\text { - Employee salary } \\
\text { payments in } \\
\text { cooperation with sharia } \\
\text { banks }\end{array}$ & $\begin{array}{l}\text { Employee } \\
\text { payments in cooperation } \\
\text { with any bank }\end{array}$ \\
\hline
\end{tabular}

Source: Primary Data 2016

Sharia hotels have a characteristic: (1) generally use attributes that refer to the needs of Muslim consumers such as the need for worship, service, and halal food; (2) Has some restrictions such as certain entertainment bans (gambling, prostitution), non-halal food (alcohol, pork), non-married couples staying in one room, and (3) gender-separated facilities and staff (spa, , Room service, room maid / boy). The characteristics of sharia hotels adopt the Islamic teachings contained in the Qur'an and Haddish.

The business of sharia hotels is growing in Surabaya city with the tourist market which is on pilgrimage, businessman and consumer of family. Sunan Ampel religious area for example was visited by about 2,000 people per day and up to 10,000 per day on a particular month (Ramadan, or other major Islamic month).Visitors region Sunan Ampel Mosque domestic tourists and about $10 \%$ of them are foreign tourists from China, France, the Netherlands, Italy, Malaysia, Saudi Arabia, Japan, Brunei, the Philippines, Germany, Greece, New Zealand, Korea, and Japan. Domestic tourists who visit mostly for worship and pilgrimage to the tomb of Sunan Ampel. While visiting foreign tourists are generally interested in building or want to learn the culture of Islam.

Table 3: Market Prospects of Sharia Hotels

\begin{tabular}{|l|l|r|}
\hline $\begin{array}{l}\mathrm{N} \\
\mathrm{o}\end{array}$ & Visitors & $\begin{array}{l}\text { Average } \\
\text { Number } \\
\text { of } \\
\text { Visitors } \\
\text { per day }\end{array}$ \\
\hline 1 & $\begin{array}{l}\text { Sunan Ampel } \\
\text { Mosque Area }\end{array}$ & 2.000 \\
\hline 2 & Cheng Ho Mosque & 1,000 \\
\hline 3 & Al Falah Mosque & 1,000 \\
\hline 4 & Al Akbar Mosque & 1.700 \\
\hline 5 & $\begin{array}{l}\text { Kemayoran } \\
\text { Mosque }\end{array}$ & 900 \\
\hline & Total & 6,600 \\
\hline
\end{tabular}

According to table 3, the number of mosque visitors daily reaches 6,600 per day and on an Islamic holy day can reach 5 times giving a big enough opportunity for accommodation around the destination. Currently there are only 11 sharia hotels with rooms ranging from 10 to 70 rooms with an average occupancy of $70 \%$. 
In addition to tourists who berziarah sharia hotel market opportunities are business people who have business in Surabaya. Some reasons consumers choose sharia hotels include: strategic location (33\%), quiet hotel atmosphere (30\%), comfortable place (21\%), interesting food menu (11\%), others (5\%). With the development of business climate in Surabaya gives a big opportunity for the development of sharia hotels.

The consumer market of the family is also quite big chances for sharia hotels. Some reasons family consumers choose sharia hotels are a safety factor for children (57\%), Islamic education (19\%), price (10\%), food (8\%) and others (6\%).

\section{Conclusion}

Sharia hotels grow and thrive due to the special needs of consumers ie Muslim consumers but remain open to non Muslim consumers. The business prospects of sharia hotels are quite good along with the development of religious tourism and other consumers.

From the SWOT analysis, the superiority aspect of sharia hotels is the learning process about the rules in Islam that can be studied by Muslin and non Muslim people. The security aspect of the hotel also becomes more value. While sharia hotels are some restrictions such as a separate pool of gender, the provision must be a husband or wife or family for a stay in one room is considered to reduce consumer comfort and difficult checking. The hotel is a consumer choice so you can choose which one suits your needs. Sharia hotels are an alternative choice for consumers who want to get specific services or facilities or want to get a different experience. 


\section{References}

i. $\quad$ Akyol \& Kilinc, 2014. Internet and Halal Tourism Marketing, Turkish Studies. International Periodical for the Languages, Literature and History of Turkish or Turkey, 9 August, pp. 171-186.

ii. Al-Hamarneh, A. \& Steiner, C., 2004. Islamic Tourism: Rethinking the Strategies of Tourism Development in the Arab World. Comparative Studies of South Asia and the Middle East, 24(1), pp. 173-182.

iii. Bhuiyan, A., Siwar, C., Ismail, S. \& Islam, R., 2011. Potentials of Islamic Tourism: A Case Study of Malaysia on the East Coast Economic Region. Australian Journal of Basic and Applied Sciences, 5(6), pp. 1333-1340.

iv. Bremer, T., 2005. Tourism and religion. In: L. Jones, ed. Encyclopedia of Religion. Detroit: McMillan.

v. COMCEC Coordination Office, 2016. Muslims Friendly Tourism: Understanding The Demand And Supply Sides In The OIC Member Countries, s.l.: COMCEC Coordination Office.

vi. Henderson, H., 2010. Sharia-Compliant Hotels. Tourism and Hospitality Research, 10(3), pp. 246-254.

vii. Henderson, J., 2003. Managing Tourism and Islam in Peninsular Malaysia. Tourism Management, Volume 24, pp. 447-456.

viii. Khan, A., Haque, A. \& Rahman, M., 2013. What Makes Tourists Satisfied? An Empirical Study on Malaysian Islamic Tourist Destination. Middle-East Journal of Scientific Research.

ix. $\quad$ Osman, F., 2015. Special. Australian Journal of Basic and Applied Sciences, 9(3), pp. 108 -112.

x. Russel, P., 1999. Religious travel in the new millennium. Travel \& Tourism Analyst, Volume 5, pp. 3968.

xi. Samori, Saturday, Z. \& Noorsalwati., 2014. Developing Malaysian Halal Standard for Hotels Industry An Exploratory Study. Procedia - Social and Behavioral Sciences , Volume 121, pp. 144-157.

xii. Santoso \& Dawn, 2007. Tourism In Islamic View. Padang: Online Magazine. [Online]

Available at: $\underline{\mathrm{http}} \mathrm{:} / /$ tabloid info.sumenep.go.id/index.php?option $=$ com content\&task=view $\&$ id $=337$ $\underline{\& \text { Itemid }}=32$ [Accessed 4 November 2010].

xiii. Timothy, D., 2007. Tourism and Islam: Consideration of culture and duty. London and New York: Routledge Taylor \& Francis Group.

xiv. Wall, G. \& Mathieson, A., 2006. Tourism: change, impacts and opportunities. Prentice Hall, Essex: Pearson. 